\title{
Pemberdayaan Masyarakat oleh Koperasi untuk Mewujudkan Kesejahteraan bagi Komunitas Petani di Daerah Cepogo
}

\author{
Mustangin ${ }^{1 *}$, Nufa Pramina Islami ${ }^{2}$, Desy Kusniawati ${ }^{3}$, Baruna Setyaningrum ${ }^{4}$, \\ Eni Prasetyawati ${ }^{5}$
}

${ }^{1}$ Pendidikan Luar Sekolah, Universitas Pendidikan Indonesia

2,3,4,5endidikan Luar Sekolah, Universitas Negeri Malang

\section{A R T I C L E I N F O \\ Article history: \\ Received 15 Januari 2018 Received in revised form 10 Februari 2018 \\ Accepted 17 Maret 2018 Available online $20 \mathrm{Mei}$ 2018 \\ Kata Kunci: \\ Pemberdayaan Masyarakat, Koperasi, Masyarakat Petani \\ Keywords: \\ Community Empowerment Cooperative, Farmer Society}

\begin{abstract}
A B S T R A K
Penelitian ini bertujuan untuk membahas tentang pemberdayaan masyarakat yang dilakukan oleh Kospin Tekun dan hasil yang diperoleh dengan adanya pemberdayaan masyarakat di Kospin Tekun. Penelitian ini merupakan penelitian yang berbasiskan pada penelitian kualitatif deskriptif. Prosedur pengumpulan data dilakukan dengan dua metode, pertama melaui wawancara kepada informan yaitu pengurus, serta petugas Kospin Tekun yang melakukan pendampingan kelompok, dan petani anggota Kospin. Kedua melalui studi dokumen dan observasi partisipan. Temuan penelitian mengungkapkan adanya proses pemberdayaan masyarakat yaitu mengupayakan masyarakat untuk lebih mudah mengakses permodalan. Dengan adanya Koperasi Simpan Pinjam (Kospin) Tekun maka masyarakat mengalami perubahan dari segi ekonomi. Dampak lain seperti terjaganya tradisi bersih desa karena masyarakat harus mengeluarkan biaya yang banyak untuk membeli kebutuhan, terdapat peningkatan pengetahuan masyarakat karena Kospin Tekun memberikan kesempatan kepada masyarakat petani untuk mengakses pengetahuan melalui pelatihan yang telah dirancang.
\end{abstract}

\section{A B S T R A C T}

This study aims to discuss about community empowerment conducted by Savings and Loans Cooperative (Koperasi Simpan Pinjam ) Tekun and the results obtained from the empowerment of the community in the Savings and Loans Cooperative (Koperasi Simpan Pinjam) Tekun. This research uses qualitative approach ddengan type of research used is descriptive. The data collection procedure was conducted by interviewing the informants to the administrators of Savings and Loans Cooperative (Koperasi Simpan Pinjam ) Tekun, Officers from Savings and Loans Cooperative (Koperasi Simpan Pinjam ) Tekun who conducted group assistance, as well as farmers who joined members of Savings and Loans Cooperative (Koperasi Simpan Pinjam ) Tekun, as well as study documents and participant observation. Research findings reveal the existence of community empowerment process that is seeking the community to more easily access the capital. With the existence of Savings and Loans Cooperative (Koperasi Simpan Pinjam ) Tekun then the community experienced economic changes. Other impacts such as maintaining the tradition name is "Bersih Desa" and the existence of these traditions the community must spend a lot to buy needs, in addition there is an increase in public knowledge because in addition to the financial program Savings and Loans Cooperative (Koperasi Simpan Pinjam ) Tekun provide opportunities for farmers in accessing knowledge through training has been designed

\footnotetext{
Corresponding author.

E-mail addresses: mustangin1992@gmail.com (Mustangin)
} 



\section{Pendahuluan}

Cepogo adalah sebuah kecamatan di Kabupaten Boyolali, Jawa Tengah, Indonesia. Masayarakat desa Cepogo mayoritas bekerja sebagai petani. Upaya membangun dan mengembangkan sektor pertanian hendaknya mengkaji semua aspek yang berkaitan dengan pertanian dan harus memperhatikan potensi yang dimiliki. Potensi tersebut yaitu potensi sumber daya alam dan potensi sumber daya manusia. Kualitas sumber daya manusia dapat dilihat melalui pendidikan. Pendidikan akan menambah pengetahuan yang secara langsung atau tidak langsung akan mempengaruhi kemampuan untu melakukan pekerjaan. Pendidikan tinggi akan membekali mereka keterampilan-keterampilan yang bermanfaat (Setiawan, 2017). Pentingnya peran masyarakat dalam pembangunan menjadikan manusia tidak lagi sebagai objek pemberdayaan akan tetapi sebagai subjek dari pemberdayaan itu sendiri (Daher, 2016). Menurut Safri Miradj dan Sumarno (2014) inti dari tujuan pembangunan adalah mewujudkan suatu masyarakat yang makmur dan sejahtera baik secara individual maupun secara sosial.

Komunitas petani merupakan masyarakat yang mendiami wilayah tertentu yang kemudian memiliki pekerjaan atau hidup sebagai petani. Pertanian menjadi salah satu sumber kehidupan bagi masyarakat untuk bertahan hidup, sehingga pertanian menjadi hal yang paling penting dalam sebuah komunitas petani. Selain itu sektor pertanian di Indonesia berdasarkan data BPS tahun 2015 (Raya, dkk, 2017) mengemukakan bahwa Sektor pertanian di Indonesia mampu menyerap tenaga kerja yang cukup besar yaitu 34\% dari populasi penduduk Indonesia, walaupun keadaan tersebut mulai menurun selama kurun waktu 10 tahun terakhir. Serapan tenaga kerja menurun sebesar 11\% pada rentang tahun 2004 sampai dengan 2014. Namun dalam pelaksanaan pertanian yang dilakukan oleh masyarakat petani terdapat berbagai permasalahan yang disebabkan berbagai faktor. Salah satu faktor adalah faktor keuangan, harga pupuk sangat sulit dijangkau petani .

Berdasarkan hal tersebut, dalam penyelenggaraan pertanian petani membutuhkan permodalan yang kuat agar dapat menghadapi berbagai permasalahan. Salah satu permasalahan adalah akses permodalan yang rumit. Jika terjadi kondisi seperti itu maka menurut Supanggih dan Widodo (2013) alternatif solusi bagi petani adalah modal usaha tani dari lembaga keuangan. Peran koperasi menjadi penting bagi petani untuk mengakses permodalan. Koperasi menurut Fitriani (2015) berfungsi membangun, mengembangkan potensi dan kemampuan ekonomi anggota untuk meningkatkan kesejahteraan ekonomi dan sosialnya.

Hubungan antara masyarakat dan koperasi adalah sangat penting, hal ini diungkapkan oleh Rufaidah (2017) yaitu koperasi dan masyarakat tidak dapat berjalan sendiri-sendiri atau bergerak terlalu dominan pada salah satu aspek, sehingga pola gerakan koperasi harus selalu beriringan dengan pola gerakan masyarakat. Oleh karena itu koperasi dapat dijadikan salah satu sumber peningkatan ekonomi masyarakat.

Berkaitan dengan hal tersebut koperasi hadir dalam rangka memenuhi permodalan petani untuk usaha pertaniannya. Koperasi juga dapat berperan dalam kegiatan pemberdayaan masyarakat. Sebelumnya telah dibahas, bahwa koperasi adalah wadah bagi masyarakat dalam mengatasi permasalahan keuangan yang ada. berdasarkan hal tersebut koperasi dapat menciptakan masyarakat yang berdaya dalam menghadapi permasalahan yang tengah dihadapinya. Koperasi mampu memberikan kontribusi untuk mengatasi permasalahan keuangan pada masyarakat petani. Hal tersebut juga diungkapkan oleh Harahap (2017) bahwa koperasi adalah gerakan ekonomi rakyat maupun badan usaha yang berperan dalam mewujudkan masyarakat yang maju, adil adil, dan makmur, oleh karena itu koperasi dianggap sebagai salah satu strategi pemberdayaan untuk membantu masyarakat menyelesaikan permasalahan yang mereka hadapi. Subandi (2009) mendefinisikan secara rinci makna dari koperasi itu sendiri, yaitu: 1) Koperasi adalah suatu perkumpulan yang didirikan oleh orang-orang yang memiliki kemampuan ekonomi terbatas, yang bertujuan untuk memperjuangkan peningkatan kesejahteraan ekonomi anggotanya, 2) Melayani anggota yang macam pelayanannya sesuai dengan macam koperasi, 3) Bentuk kerjasama di dalam organisasi koperasi bersifat terbuka dan sukarela, 4) Masing-masing anggota koperasi mempunyai hak dan kewajiban yang sama, 5) Masing-masing anggota koperasi berkewajiban untuk mengembangkan serta mengawasi jalannya koperasi dan 6) Resiko dan keuntungan koperasi ditanggung dan dibagi secara adil

Salah satu koperasi yang menjadi topik dalam penelitian ini adalah Koperasi Simpan Pinjam (Kospin) Tekun yang ada di Cepogo, Boyolali. Koperasi Simpan Pinjam (Kospin) Tekun menjadi hal penting bagi masyarakat petani yang ada di daerah Cepogo. Banyak masyarakat dari Cepogo mendapatkan keuntungan dari adanya Koperasi Simpan Pinjam (Kospin) Tekun ini. Oleh karena itu pada penelitian ini akan membahas tentang pemberdayaan masyarakat yang dilakukan oleh Kospin Tekun dan hasil yang diperoleh dari adanya pemberdayaan masyarakat di Kospin Tekun ini. 


\section{Metode}

Dalam penelitian menggunakan pendekatan kualitatif deskriptif. Penelitian ini menggunakan pendekatan kualitatif untuk mengungkap data-data pemberdayaan masyarakat melalui koperasi dan hasil yang ada dari pemberdayaan masyarakat tersebut. Sedangkan jenis penelitian ini adalah studi deskriptif, karena dalam penelitian ini akan mendeskripsikan pemberdayaan masyarakat yang dilakukan oleh Koperasi Simpan Pinjam Tekun yang ada di Cepogo Boyolali, serta hasil-hasil pemberdayaan masyarakat tersebut.

Partisipan dalam penelitian ini adalah para informan yang memiliki keterkaitan (memiliki simpanan) pada Kospin Tekun di daerah cepogo. Selain itu partisipan penelitian ini adalah pengurus kospin Tekun itu sendiri. Prosedur pengumpulan data merupakan langkah yang paling strategis dalam penelitian. Tahapan pengumpulan data pada penelitian ini, sebagai berikut.

\section{Wawancara}

Pengumpulan data yang sangat penting dalam penelitian ini berupa data yang diambil melalui tanya jawab kepada narasumber (informan). Informan yang dimaksud adalah pengurus koperasi, pengurus koperasi yang mendampingi masyarakat, serta masyarakat petani yag tergabung dalam Kelompok Tani Sari Mulyo dan Kelompok Tani Lestari Manunggal. Untuk mengumpulkan informasi, peneliti menggunakan teknik wawancara tidak terstruktur atau wawancara mendalam dalam berbagai situasi. Ini bertujuan untuk menciptakan suasana akrab antara peneliti dan informan. Keakraban ini dilakukan guna mendapatkan data yang punya kedalaman dan rinci, dan akurat.

\section{Observasi Partisipan}

Pengumpulan data melalui observasi dilakukan oleh peneliti dengan mengkuti kegiatan yang dilakukan oleh partisipan. Salah satunya ikut secara langsung dalam aktivitas petani. Selain itu peneliti juga ikut dalam kegiatan pengurus koperasi dalam melaksanaka kegiatan pendampingan kepada masyarakat secara langsung untuk mendapatkan gambaran yang nyata dari kegiatan pendampingan tersebut untuk melengkapi data utama.

\section{Studi Dokumen}

Pengumpulan data ini dengan mengkaji dokumen-dokumen yang terkait dengan penelitian ini. Hal tersebut digunakan sebagai data tambahan untuk mendukung data utama yang di dapat dari teknik pengumpulan data sebelumnya. Diharapkan data yang didapatkan lebih banyak dan informatif untuk menjawab permasalahan penelitian yang diajukan.

\section{Hasil dan pembahasan}

\section{Pemberdayaan Masyarakat oleh Koperasi Tekun}

Boyolali merupakan daerah pertanian dimana daerah tersebut berada di lereng gunung merbabu tepatnya sebelah utara gunung mearapi. Masyarakat desa boyolali sebagian besar bermata pencaharian sebagai petani sayuran, biasa disebut petani tumpangsari. Peternakan yang dominan adalah ternak sapi dan kambing. Umumnya pada satu lahan pertanian di dusun gebyog desa selo kecamatan selo ditanami beberapa jenis tanaman dan hal itu menyebabkan petani membutuhkan banyak pupuk, maka kebutuhan akan pemenuhan pupuk sangat tinggi. Fakta lainnya didaerah ini peredaran uang sangat tinggi, oleh sebab itu masyarakat membutuhkan suatu lembaga keuangan untuk membantu mereka mengatasi masalah keuangan dalam hal permodalan. Berdasarkan hal tersebut dibentuklah koperasi Kospin Tekun yang dapat membantu masyarakat memperoleh modal untuk melakukan kegiatan pertanian.

Kospin Tekun merupakan salah satu koperasi simpan pinjam yang berdiri di daerah Cepogo i yang bisa digunakan oleh masyarakat Cepogo untuk dapat terlayani dalam hal keuangan salah satunya adalah untuk permodalan. Berdasarkan data yang diambil dari data Kospin Tekun diketahui bahwa Kospin Tekun lahir sebagai bentuk institusi follow up Proyek Pengembangan Pedesaan Terpadu atau Integrated Rural Development Project (IRDP) kerjasama antara LPTP Surakarta dengan BORDA Jerman di wilayah kecamatan Cepogo, Ampel dan Selo kabupaten Boyolali propinsi Jawa Tengah yang bertujuan untuk memperkuat struktur sosial, ekonomi dan lingkungan hidup masyarakat di wilayah lereng gunung Merapi dan Merbabu.

Proyek IRDP berlangsung selama 10 tahun dari tahun 1989 dan berakhir tahun 1998. Selama masa proyek, IRDP membentuk dan memperkuat kelompok-kelompok masyarakat seperti kelompok tani, kelompok ternak, kelompok konservasi, kelompok pengrajin, kelompok biogas dan lain sebagainya, yang 
anggotanya adalah warga masyarakat yang berada di wilayah lereng gunung Merapi dan Merbabu. Anggota kelompok memperoleh berbagai pelatihan dibidang pertanian, peternakan, konservasi tanah dan air, peemanfaatan limbah ternak untuk energi alternatif biogas dan sebagainya serta memperoleh bantuan modal untuk usaha dalam bidang agribisnis. Kemudian tahun 1996 mulai dirintis kegiatan revolving fund $(R F)$ atau dana bergulir yang kemudian menjadi cikal bakal koperasi setelah proyek IRDP selesai.

Koperasi menjadi alternatif pilihan institusi yang dirasa paling sesuai dan diharapkan bisa menjadi wadah bagi kelompok-kelompok masyarakat untuk pengembangan ekonomi di wilayah pedesaan khususnya bagi masyarakat petani. Hal tersebut sesuai dengan yang diungkapkan oleh Sumodiwirjo (1985) bahwa petani perlu didik dalam lapangan organisasi yang dapat memperkuat kedudukannya baik ekonomi maupun sosial, maka koperasilah macam organisasi yang tepat. Oleh sebab itu keberadaan koperasi menjadi bagian yang tidak dapat dipisahkan dalam rangka mencapai kesejahteraan masyarakat petani. Merujuk dari Fungsi dan peran koperasi yang tertulis dalam UU No.25 tahun 1992 tentang perkoperasian adalah sebagai berikut: 1) Membangun dan mengembangkan potensi dan kemampuan ekonomi anggota pada khususnya dan masyarakat pada umumnya untuk meningkatkan kesejahteraan ekonomi dan sosialnya; 2) Berperan serta secara aktif dalam upaya mempertinggi kualitas kehidupan manusia dan masyarakat; 3) Memperkokoh perekonomian rakyat sebagai dasar kekuatan dan ketahanan perekonomian nasional dengan koperasi sebagai sokogurunya; dan 4) Berusaha untuk mewujudkan dan mengembangkan perekonomian nasional yang merupakan usaha bersama berdasar atas asas kekeluargaan dan demokrasi ekonomi.

Seperti yang telah diuraikan diatas bahwa masyarakat petani mengalami kesulitan dalam hal permodalan untuk melaksanakan kegiatan pertaniannya. Hal tersebut juga pernah dialami oleh masyarakat petani di Boyolali sehingga masyarakat memanfaatkan adanya koperasi simpan pinjam itu untuk mengatasi permasalahan tersebut. Karena modal dalam menggarap pertanian itu yang tidak sedikit, misalnya saja untuk membeli bibit dan pupuk yang menjadi hal utama dalam pertanian. Sebagaimana hal tersebut juga diungkapkan oleh Subandi (2009) Koperasi Simpan Pinjam adalah koperasi yang bergerak dalam pemupukan simpanan dari para anggotanya untuk dipinjamkan kembali kepada anggotanya yang membutuhkan bantuan modal untuk usahanya. Adanya koperasi membantu masyarakat petani dalam meningkatkan usahanya kearah yang lebih baik.

Selain menyediakan modal kepada masyarakat, Koperasi Simpan Pinjam (Kospin) Tekun juga mengadakan dampingan kepada kelompok masyarakat yang disebut dengan kelompok pendampingan. Bentuk pendampingan berupa pemberian pelatihan kepada kelompok anggota Kospin Tekun. Pelatihan i diadakan sesuai dengan permintaan anggota. Tema setiap kegiatan pendampingan juga disesuaikan dengan kebutuhan masyarakat, misalnya pelatihan tentang ternak, pertanian dan lain sebagainya. Semua pembiayaan untuk pelatihan ditanggung pihak Kospin. Pada pelatihan peternakan pihak Kospin Tekun mendatangkan narasumber ahli peternakan, dan untuk biaya narasumber atau tutor ditanggung pihak Kospin Tekun. Berikut ini hasil dokumentasi yang didapat oleh peneliti saat kegiatan diskusi antara kelompok tani dan pengurus Kospin Tekun: 


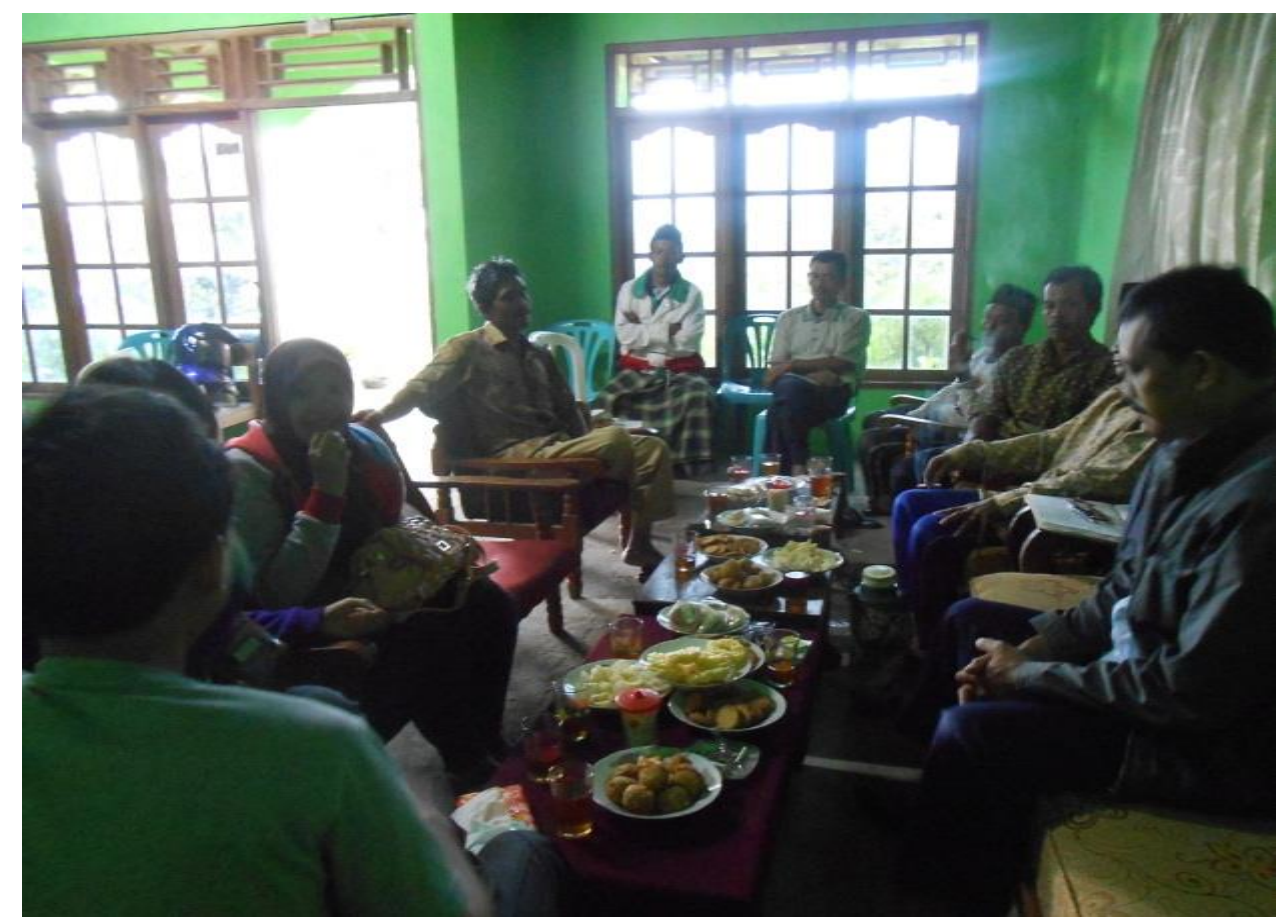

Gambar 1. Kegiatan Diskusi yang dilakukan oleh Pihak Kospin dan Anggota (Sumber: Dokumentasi Peneliti)

Berbagai bentuk kegiatan pendidikan yang telah digagas oleh Kospin Tekun dimaksudkan agar anggota yang berasal dari kelompok petani memiliki wawasan mengenai cara pengolahan pertanian secara modern dan juga memiliki wawasan pengolahan teknologi untuk peternakan. Sehingga masyarakat tidak hanya kuat dalam hal permodalan, namun juga memiliki kekuatan dalam pengetahuan dan keterampilan dalam mengolah kegiatan pertanian yang lebih baik.

\section{Hasil Pemberdayaan Masyarakat oleh Koperasi Tekun}

\section{Perubahan Perekonomian Masyarakat}

Dengan adanya Koperasi Tekun maka masyarakat mengalami perubahan dari segi ekonomi. Hal ini bisa dilihat dari kesejahteraan anggota suatu kelompok dalam masyarakat. seperti terlihat dari banyaknya investasi masyarakat dalam bentuk hewan ternak, yang merupakan hasil pinjaman maupun tabungan kelompok. Perubahan masyarakat tersebut dapat dikategorikan sebagai bentuk pemberdayaan masyarakat, menurut Mustangin (2017) peberdayaan masyarakat bertujuan memberikan peluang kepada masyarakat untuk dapat mencapai pemecahan masalah yang dihadapi. Koperasi Tekun datang untuk membantu masyarakat mendapatkan akses permodalan sehingga masyarakat dapat memenuhi kebutuhan mereka.

Dilihat dari kondisi masyarakat yang masih menjaga tradisi budaya bersih desa sehingga masyarakat membutuhkan banyak biaya untuk melaksanakan acara bersih desa. Dalam kegiatan ini masyarakat memerlukan biaya sekitar 2.000.000, sehingga secara langsung masyarakat membutuhkan dana tambahan. Pada kondisi ini masyarakat dapat memanfaatkan Koperasi Tekun. Selain itu ada beberapa kelompok yang memanfaatkan SHU yang dibagikan secara kelompok dalam bentuk bingkisan berupa bahan makanan yang juga bisa digunakan untuk acara bersih desa.

Pendirian Koperasi Tekun yang berbasis idealisme menjadikan pengelolaan koperasi sangat transparan dan jujur. Dalam budaya yang bersikap transparan itu yang ditiru oleh kelompok masyarakat. Adanya RAT (Rapat Anggota Tahunan) dimana sebagai jalan penghubung antara Koperasi Tekun dengan para kelompok Tani yang selalu ikut berpartisipasi dalam kegiatan dan pemecahan masalah atau menentukan ke depan menjadikan budaya partisipasi antar kelompok lebih nampak di lakukan di masyarakat dalam kehidupan sehari-hari. Hal lain yang merupakan kontribusi Kospin Tekun adalah memfasilitasi kelompok tani untuk mendapatkan informasi untuk mengikuti pameran produk, sehingga masyarakat bisa berpartisipasi dalam pelaksanaan pameran tersebut.

\section{Peningkatan Pengetahuan Masyarakat}

Selain menyediakan modal kepada masyarakat Koperasi simpan pinjam (Kospin) Tekun juga mengadakan kepada kelompok masyarakat yang disebut dengan kelompok dampingan berupa pemberian 
pelatihan kepada kelompok yang menjadi anggota dari Kospin Tekun seperti pelatihan tentang ternak, pertanian dan lain sebagainya. Dalam pelatihan ini pihak Kospin Tekun menanggung semua biaya. Selain itu anggota Kospin Tekun juga memiliki kesempatan untuk program wisata yang ada kaitannya dengan pertanian ataupun peternakan. Hal ini dimaksudkan agar anggota yang berasal dari kelompok petani memiliki wawasan mengenai cara pengolahan pertanian secara modern dan juga memiliki wawasan pengolahan teknologi untuk peternakan.

Berdasarkan hal tersebut maka Kospin Tekun memiliki andil dalam peningkatan pengetahuan masyarakat. Sehingga tidak hanya peningkatan perekonomian dari adanya pelayanan permodalan yang ada di Kospin Tekun. Tetapi juga ada aksi pendidikan yang dilakukan oleh Kospin Tekun kepada masyarakat. Hal ini sesuai dengan makna maupun pengertian pemberdayaan masyarakat yaitu upaya untuk memampukan masyarakat agar masyarakat mampu bertahan. Hal serupa juga diungkapkan Kapitsa (dalam Sohail, 2014) pemberdayaan masyarakat ber-arti kekuatan untuk melakukan perubahan dalam masyarakat dengan menggerakkan sumber daya yang ada serta pemanfaatan peluang untuk perubahan dalam masyarakat. Penggerakan tersebut seperti adanya pendidikan dan pelatihan kepada masyarakat sedangkan untuk pemanfaat peluang yaitu adanya program wisata yang dilakukan oleh pihak Kospin Tekun yang juga digunakan sebagai sarana belajar bagi masyarakat untuk dapat belajar dari pihak lain melalui wisata yang dilakukannya tersebut.

Perubahan masyarakat terjadi dengan semakin adanya peningkatan pengetahuan dan keterampilan dalam hal bertani dan beternak masyarakat. Perubahan tersebut memungkinkan masyarakat untuk dapat tumbuh dan berkembang mengikuti kemajuan bidang pertanian. Selain itu dengan adanya perubahan pengetahuan keterampilan masyarakat, maka akan tercapai kesejahteraan masyarakat itu sendiri karena mampu menghadapi permasalahan yang dihadapi terkait dengan pertanian.

\section{Terjaganya tradisi di Masyarakat}

Kondisi masyarakat yang masih ada budaya bersih desa. dari adanya budaya itu masyarakat harus mengeluarkan biaya yang banyak untuk membeli kebutuhan masyarakat. untuk itu masyarakat memanfaatkan Koperasi Tekun untuk membantu pembiayaan dalam tradisi bersih desa. sehingga kelestarian budaya tetap terjaga. Selain itu dengan masih terjaganya tradisi bersih desa yang masih lestari akan berdampak pada sosial budaya masyarakat, hal ini terlihat dari kegiatan silahturahim yang bertujuan mempererat hubungan sosial masyarakat boyolali. Sehingga secara langsung Koperasi Tekun memberikan dampak sosial yang positif untuk bisa mempererat keharmonisan masyarakat antar dusun bahkan antar desa.

Disamping itu ada suatu tradisi yang bernama bersih desa. Bersih desa ini merupakan suatu kegiatan rutin setiap tahun yang diadakan oleh masyarakat desa tersebut. Acara berupa pesta besarbesaran dan memerlukan dana yang cukup besar. Fungsi dari bersih desa seperti yang telah disebutkan adalah untuk silaturahmi seperti Hari Raya Idul Fitri tetapi lebih besar bersih desa. Sehingga masyarakat harus menyediakan banyak dana untuk memepersiapkan acara tersebut karena pada setiap acara bersih desa tersebut selalu menyembelih sapi. Dalam acara ini juga mengundang warga desa lain untuk ikut berpartisipasi dalam acara bersih desa tersebut. Tradisi Bersih Desa ini merupakan tradisi akbar yang ada di Masyarakat. Sehingga adanya Tradisi Bersih Desa akan mengeluarkan dana yang tidak sedikit, sekitar dua juta rupiah yang harus dikeluarkan oleh masyarakat. Masyarakat membutuhkan dana tambahan dari pihak lain. Sehingga masyarakat memilih memanfaatkan Koperasi Tekun. Jika dilihat dari indikator keberdayaan masyarakat bahwa masyarakat berdaya jika dapat memenuhi kebutuhan primernya. Seperti yang diungkapkan oleh Dewi dan Widiastuti (2016) Salah satu indikator masyarakat miskin telah mengalami pemberdayaan ekonomi adalah dengan meningkatnya kemampuan daya beli (konsumsi) masyarakat untuk memenuhi kebutuhankebutuhan hidup yang meliputi makanan, pakaian, rumah, pendidikan, kesehatan dan rekreasi. Hal yang terjadi di daerah boyolali lebih dari itu, masyarakat mampu untuk memenuhi kebutuhan yang lain untuk menjaga tradisi yang ada di masyarakat. Selain itu ada beberapa kelompok yang memanfaatkan SHU yang dibagikan kelompok dalam bentuk bingkisan berupa bahan makanan yang juga bisa digunakan untuk acara bersih desa.

\section{Simpulan dan saran}

Koperasi Simpan Pinjam (Kospin) Tekun merupakan lembaga keuangan yang berdiri atas keinginan masyarakat setelah program kerjasama antara LPTP Solo dengan BORDA Jerman. Koperasi Tekun memiliki simpanan harian dan tahunan. Dengan adanya Koperasi Simpan Pinjam ini masyarakat akan lebih mudah dalam mengakses permodalan untuk operasional usaha pertanian dan peternakan. Dengan adanya Koperasi Simpan Pinjam (Kospin) Tekun maka masyarakat mengalami perubahan dari segi ekonomi. Hal ini bisa dilihat dari kesejahteraan anggota suatu kelompok dalam masyarakat. seperti terlihat dari banyaknya investasi masyarakat dalam bentuk hewan ternak, yang merupakan hasil 
pinjaman maupun tabungan kelompok. Banyak dampak lain yang terlihat dari segi ekonomi adalah adanya pedagang yang mengembangkan usaha baru yang berada diluar boyolali. Kontribusi lainnya membantu terjaganya tradisi masyarakat, dengan mengurangi beban pembiayaan untuk melaksanakan tradisi bersih desa.

\section{Daftar Rujukan}

Daher, Irawan Syarifuddin . 2016. Pemberdayaan Masyarakat Melalui Koperasi Kasongan Usaha Bersama (Kub) Di Desa Wisata Kasongan Bantul Yogyakarta . Jurnal Universitas Yogyakarta tersedia journal.student.uny.ac.id/ojs/index.php/pls/article/viewFile/1394/1268.

Dewi, D.S \& Widiastuti, T. (2016). Pemberdayaan Ekonomi Karyawan Pesantren Oleh Koperasi AlMawaddah Studi Kasus Pesantren Putri Al-Mawaddah. Jurnal Ekonomi Syariah Teori dan Terapan, 3(3), 219-234

Fitriani. (2015). Penguatan Kapasitas Kelembagaan Gapoktan Melalui Pembentukan Koperasi Pertanian. Masyarakat, Budaya, dan Politik, 28(2), 63-69

Harahap, F.I.N. (2017). Pemberdayaan Masyarakat Pemulung Sampah Sungai CitarumMelalui Koperasi Bangkit Bersama. Jurnal Pendidikan dan Pemberdayaan Masyarakat. 4(2). 180-186. http://dx.doi.org/10.21831/jppm.v4i2.15253

Mustangin, M. (2017). Perubahan iklim dan aksi menghadapi dampaknya: Ditinjau dari peran serta perempuan Desa Pagerwangi. Jurnal Pendidikan dan Pemberdayaan Masyarakat, 4(1), 80-89. http://dx.doi.org/10.21831/ippm.v4i1.13051

Raya, A.B, dkk. (2017). Tantangan Literasi Informasi Petani Di Era Informasi: Studi Kasus Petani di Lahan Pasir Pantai Daerah Istimewa Yogyakarta. Jurnal Sosial Ekonomi Pertanian. 10(1), 10-16

Rufaidah, E. (2017). Pemberdayaan Perekonomian Masyarakat Melalui Koperasi Unit Desa Berbasis Usaha Terbimbing. Akademika, 22 (2), 361-374.

Safri Miradj dan Sumarno. 2014. Pemberdayaan Masyarakat Miskin, Melalui Proses Pendidikan Nonformal, Upaya Meningkatkan Kesejahteraan Sosial di Kabupaten Halmahera Barat. Jurnal. Pendidikan dan Pemberdayaan Masyarakat. (Vol 3. No 1). Halaman 102 http://journal.uny.ac.id/index.php/jppm/article/view/2360/1959.

Setiawan, Tomi Uki, Ahmad Taufiq, Lusia Astrika. 2017. Pemberdayaan Masyarakat Berbasis Koperasi Pada Tambang Minyak Tradisional Desa Bangoan Kecamatan Jiken Kabupaten Blora. Journal of Politic and Government Studies Volume 6 Nomor 4.

Subandi. (2009). Ekonomi Koperasi: Teori dan Praktik. Jakarta: Alfabeta

Supanggih, D \& Widodo, S. (2013). Aksesibilitas Petani Terhadap Lembaga Keuangan: Studi Kasus Pada Petani di Desa Sidodadi, Kecamatan Sukosewu, Kabupaten Bojonegoro). Agriekonomika, 2(3), 163-173

Undang-Undang Nomor 25 Tahun 1992 Tentang Perkoperasian 